\title{
ROMANIA AND ROMANIAN ORTHODOX CHURCH THROUGH THE VIEW OF PATRIARCH CYRIL OF BULGARIA ACCORDING TO HIS "DIARIES"
}

\author{
Assist. Prof. Dr. Ventzislav KARAVALTCHEV, \\ Faculty of Theology, University of Sofia, \\ BULGARIA, \\ E-mail: ventzislav_k@hotmail.com
}

\begin{abstract}
The present article discusses the attitude of Patriarch Cyril of Bulgaria to Romania and the Romanian Orthodox Church. His attitude is reflected in his memories and impressions from the Romanian country, as he himself has preserved them in his "Diaries". These impressions were formed by his Romanian teachers - professors from the Faculty of Theology in Chernivtsi and his several meetings with the patriarch Justinian of Romania, Romanian clergy and lay people during his unforgettable visits to Romania. With much love and respect, he speaks about Romania, Romanian people, the achievements of the Romanian Church and about the friendship that has connected Bulgaria and Romania.
\end{abstract}

Keywords: Patriarch Cyril of Bulgaria; Patriarch Justinian of Romania; Romanian Orthodox Church; Bulgarian Orthodox Church; church; monastery; communism priests; clergy;

\section{INTRODUCTION}

One of the greatest names in the modern history of the Bulgarian Orthodox Church is that of Patriarch Cyril. An exceptional cleric, a Christian, a man, a scientist, he left a bright trace not only in the Bulgarian but also in the world history. For his readiness to sacrifice himself, but to save the Bulgarian Jews from a certain death, for the fact that thousands of people were saved by him and other Bulgarian clergy man, in 2001 the grateful state of Israel declared him " The Righteous Among The Nations ". ${ }^{1}$ Patriarch Cyril of Bulgaria (birth name: Konstantin Markov Konstantinov) was born on 16.01.1901 in Sofia.

Some biographers who do not sympathize him are trying to discredit his person with the claim that he has Albanian origin and was almost unlawfully elected as Patriarch. ${ }^{2}$ Their claim, which is based solely on the fact that Patriarch Cyril's father, Konstantin Pachu, is coming to Bulgaria from Albania does not automatically turn the Patriarch ethnicity into an Albanian. Moreover, the family of the father of Patriarch Cyril comes from the village of Granova (Albania), where the predominant population was Bulgarian, there were also Albanians, Greeks and Vlachos. The lack of sufficient documents and testimonies does not allow this issue to be finally resolved even today. There is evidence that the greatgrandfather of Patriarch Cyril was a priest and his great-great-grandfather Michael was a

\footnotetext{
1 Righteous Among the Nations Honored by Yad Vashem by 1 January 2017 http://www.yadvashem.org/yv/pdf-drupal/bulgaria.pdf visited 06.04.2018.

2 Димов, Я. Кирил „Патриарх Български“. София, 2005, pp. 67, 73 и сл. Димов, Я. Не си прави кумир. Ч. I, София, 1992, pp. 152-159.
} 
bishop of one of the Albanian eparchies today. ${ }^{3}$ His primary education, future Patriarch Cyril, received in Sofia. ${ }^{4}$ He then enrolled in the Sofia Theological Seminary, which ended in 1920. In the period 1920 - 1923 he attended the Theological Faculty of the Belgrade University. On December 30, 1923, he was tonsured for a monk in the church "Holy Nedelya" in Sofia, where he was named Cyril. The next day he was ordained a deacon. $\mathrm{He}$ worked for a while in the office of the Sofia Metropolitan house and as a secretary in the office of the Rila Monastery, and then as a teacher at the Sofia Theological Seminary.

During the 1924 he studied in the Faculty of Philosophy at the University of Zagreb, and the following year in the Theological Faculty of the University of Chernivtsi, where in 1927 he was awarded a PhD in Theology. Between 1928 and 1929 he did a specialization in the Faculties of Philosophy in the Universities of Vienna and Berlin. On December 5, 1931, he was appointed a protosynkellos of the Sofia Metropolis, and in 1932 he was introduced to san archimandrite. From September 1932 to March 1935 he was Head of the Cultural and Educational Department of the Holy Synod of the Bulgarian Orthodox Church and then until May 1938 he was Secretary of the Holy Synod of the Bulgarian Orthodox Church. On July 12, 1936, he was ordained bishop at the temple "St. Alexander Nevsky" with the title "Stobijski".

On May 15, 1938, he was elected, and on 29 May he was canonically established for Metropolitan of city of Plovdiv. Between 1939 and 1945, he also ruled the Diocese of Maronia of the Bulgarian Orthodox Church (today in Greece). From January 3, 1951 to May 10, 1953, he is a deputy chairmen of the Holy Synod of the Bulgarian Orthodox Church. After the restoration of the patriarchal dignity of the Bulgarian Orthodox Church during the Third Church-People's Council of Bulgarian church on May 10, 1953, with 104 from 107 votes, he was elected by three candidates for a Bulgarian Patriarch. Until his blessed death, on March 7, 1971, he was permanently occupying the Patriarchal throne in the Bulgarian Church. His rule coincided with the most difficult years in the history of the Bulgarian Church - the period of communism, which confronted Patriarch Cyril with numerous problems and challenges, most of which he managed to overcome with dignity. Patriarch Cyril is the holder of many prestigious Bulgarian and international awards, he is Doctor Honoris causa of the Sofia, Moscow and Leningrad Academies of Theology, author of dozens of scientific papers, books, articles and publications, academician of Bulgarian Academy of Science. Years of training in various leading Bulgarian and European educational institutions, besides the deep knowledge in various fields of theology, philosophy and law, also provided a rich foreign language training. One of the many languages that Patriarch Cyril knew and used was also the Romanian language. ${ }^{5}$ With the studying of the Romanian language, he was mainly involved during his specialization in Chernivtsi. ${ }^{6}$

During his journey to and from Chernivtsi, was his first acquaintance with Romania, with the Romanian people, with their life, culture and religiousness. Unfortunately, we don't have account of his impressions from this first trip through

\footnotetext{
3 Павлов, П. Патриарх Кирил: опит за жизнеописание. - В: Сборник в чест на Кирил патриарх Български. Пловдив, 2001, p. 13. Ковачев, М. Негово Светейшество Българският патриарх Кирил и преглед на книжовното му дело. - ГДА, т. XIII, 1964, p. 347.

${ }^{4}$ Димов, Я. Не си прави..., p. 152.

5 Омарчевски, А. Участието на Негово Светейшество Патриарх Кирил във възстановяването на Българската Патриаршия. - В: Сборник в чест на Кирил Патриарх Български (по случай 100 години от рождението и 30 години от неговата смърт). Пловдив, 2001, pp. 57-60.

${ }^{6}$ Ibidem.
} 
Romania. But we have such from his subsequent trip in July 1948, when he visited Moscow as a member of Bulgarian Orthodox Church delegation for the celebration of the 500th anniversary of the Russian Orthodox Church autocephality. ${ }^{7}$ During this trip to Moscow, which took place on 5 July 1948, the plane landed in Bucharest for about an hour and took over the Romanian delegation headed by Patriarch Justinian (1901-1997). ${ }^{8}$ At the airport in Bucharest, the Bulgarian ecclesiastical delegation was solemnly welcomed by a large number of Romanian clerics led by the Vicar Bishop of Patriarch Justinian. Personally, here came the Minister of Religious Cults in Romania, Mr. Stănchu Stoyan, and his secretary father Vaska, something, which greatly impresses Patriarch Cyril. ${ }^{9}$ Patriarch Cyril kindly spoke about some of the members of the Romanian delegation, he obviously knew well from their previous meetings: Prof. T. Popescu, Prof. P. Vintilescu, Prof. Ioan Comana and others. ${ }^{10}$

The newly elected Romanian patriarch Justinian, along with his accompanying Romanian clerics, boarded the same plane and together they continued the trip to Moscow. Patriarch Justinian was a close friend of the future Bulgarian Patriarch Cyril, something that is evident not only from the subsequent conversation between them on the board of the plane, but also from many subsequent events. From their conversation on the plane, it became clear that Patriarch Cyril, then Metropolitan of Plovdiv, was part of the Bulgarian delegation for the enthronement of Patriarch Justinian a little earlier same year, on $6^{\text {th }}$ of June 1948. ${ }^{11}$ Patriarch Cyril reminded his interlocutor of his words during the enthronement speech at the Church of St. Spyridon in Bucharest on the occasion of the concordat between Romania and the Vatican, to which Patriarch Justinian responded: "While we are in Moscow, the concordant will be denounced". ${ }^{12}$ Patriarch Justinian's words turn out to be prophetic, not only the concordat was denounced, but in 1950 Romania broke its diplomatic relations with the Vatican. ${ }^{13}$ Patriarch Cyril appears to be also well acquainted with the geography of Romania, and although from the air, from the porthole of the plane he knew well, when he flew over Galatz, over Braila or Blata. ${ }^{14}$ During the meeting in Moscow, as well as during the trips intentionally organized by the Soviet state, Patriarch Cyril repeatedly mentioned his personal meetings with Patriarch Justinian and the other members of the Romanian delegation, sharing his personal positive impressions from them. ${ }^{15} \mathrm{He}$ also did not omitted to mention the solemn lunch given by the Romanian ambassador in Moscow, Prof. Vladesko Rakosha, in honor of Patriarch Justinian on July $19,1948,{ }^{16}$ as well as his conversation with Priest Prof. Vintilescu on the Higher Theological Education in Romania and the reforms in it. ${ }^{17}$

\footnotetext{
Деяния совещания глав и представителей автокефальных Православных церквей в связи с празднованием 500 летия автокефалии Русской Православной церкви $8-18$ июля 1948 г. Т. 1. Москва, 1949.

${ }^{8}$ Кирил Патриарх Български. Дневници (съст. И ред. Ж. Лефтеров, М. Методиев). София, 2018, p. 73.

${ }^{9}$ Ibidem.

${ }^{10}$ Ibidem, pp.73, 75, 83 .

${ }^{11}$ Ibidem, p.73

12 Ibidem.

${ }^{13}$ Stanciu, C. A Rebirth of Diplomacy: The Foreign Policy of Communist Romania between Subordination and Autonomy, 1948-1962. - Diplomacy \& Statecraft, vol.24, issue2, 2013, pp. 253-272.

${ }^{14}$ Кирил Патриарх Български. Днивници..., p.74.

${ }^{15}$ Ibidem, pp. 76, 82-83, 107, 110, 122.

${ }^{16}$ Ibidem, p. 110

${ }^{17}$ Ibidem, p.75.
} 
On July 14, 1951, future Patriarch Cyril on his way to Moscow again landed shortly in Bucharest, ${ }^{18}$ and on July 17 he had a special meeting with Patriarch Justinian in Moscow, where they discussed the status of the theological institutes in Romania, the number and status of professors and students in the Theological Schools, the Church's social security funds, the auxiliary funds of the Church, Church workshops and other important issues. ${ }^{19}$ Describing Patriarch Justinian briefly, Patriarch Cyril says: "... a little gray beard. Diabetes". ${ }^{20}$ On July 20, 1951, after the All-night Vigil at the Kremlin church of Epiphany in Moscow, Patriarch Justinian again talked with Patriarch Cyril and the topic of the conversation again was focused on the theological education and the problems with theological staff. ${ }^{21}$ On 24 July 1951 in Moscow, Patriarch Justinian visited Patriarch Cyril and talked again about the Church's problems and especially about the financial policies of Romanian church. ${ }^{22}$

During the celebrations in Prague on the occasion of the proclamation of the Autocephality of the Czech Orthodox Church in December 1951, Patriarch Cyril had an interesting meeting with Bishop Dr. Antim Nika, Vicar of Patriarch Justinian, who had written a $\mathrm{PhD}$ dissertation on Christianity among Muslims in the Near East, from which Patriarch Cyril was very interested. ${ }^{23}$ Patriarch Cyril himself worked for a while on studying the life, language and traditions, as well as on the conversion to Christianity of Muslim Bulgarians in the Rhodope mountain area. ${ }^{24}$

In July 1952, Patriarch Cyril on his way to Vienna again crossed Romania, but this time with a train on the Giurgiu-Bucharest-Arad route, having again in Bucharest a special meeting with his friends in the Romanian Patriarchate. In this case he met Patriarch Justinian and the Metropolitans Filaret and Teoctist, as well as the painter Konstantin Petrescu. The Bulgarian delegation was again very warm welcomed, Patriarch Cyril laconically noted: "... 600 priests". ${ }^{25}$ Because there is no clarification in Patriarch Cyril's Diaries, it is probably here mentioned, that only in Bucharest there are 600 priests and not that he was solemnly welcomed by such a large number of clergymen. In the Patriarchy they talked again about the finances of the Church, monasteries and other ecclesiastical problems. ${ }^{26}$

The brotherly love and close relations between Patriarch Justinian and Patriarch Cyril were also marked by an extraordinary event in the recent history of the Bulgarian Church - Restoration of Patriarchal dignity of the Bulgarian Orthodox Church and the election of a new Bulgarian Patriarch on May 10, 1953. At the inauguration ceremony of the newly elected Bulgarian Patriarch, delegations from different Orthodox churches arrived in Sofia, but only the delegation of the Romanian Orthodox Church was headed by the Patriarch Justinian, all others delegations were led by Metropolitans. ${ }^{27}$ In his speech on the election and enthronement of Patriarch Cyril, Patriarch Justinian emphasized the deep historical ties that connect the Bulgarian and Romanian people and our two Churches. His

\footnotetext{
${ }^{18}$ Ibidem, p. 154.

${ }^{19}$ Ibidem, p. 157

${ }^{20}$ Ibidem.

${ }^{21}$ Ibidem, p. 159.

${ }^{22}$ Ibidem, p. 161

${ }^{23}$ Ibidem, p.74.

${ }^{24}$ Вж: Патриарх Кирил. Българомохамедански селища в Южни Родопи: Топонимно, етнографско и историческо изследване. София, 1960.

${ }^{25}$ Кирил Патриарх Български. Дневници..., р. 174.

${ }^{26}$ Ibidem.

${ }^{27}$ Деяния на III Църковно-народен събор 8-9 май 1953. София, 1954, pp. 186-189.
} 
sincere words were an eloquent testimony to this: "Our Holy Synod, inspired by great love, which has been experiencing for centuries to the Bulgarian Church, has empowered us to witness this love through live speech and to take part in these celebrations as a sign of great respect to Your Holiness, the First Hierarch of the Bulgarian Church, when you, according to the Orthodox tradition receives from the Holy Synod, the installation and the enthronement ... The people living in today's territories of Romania and Bulgaria have fraternized and allied with the Slavs in the same Christian faith, the same priests in the same churches, around the same diocese. Among the most ancient Danubian dioceses there was the Drustar Fortress, where the first Bulgarian Patriarch Damyan headed over forty years the Bulgarian and Romanian Churches... The acts constitute the most vivid expression of feelings. For the unceasing love and brotherhood of the Romanian Church and the Romanian people towards the Bulgarian people, since they since they've got to know them and up to today, speaks the deeds recorded in the ecclesiastical and monastery written documents of your country, speaks the liturgical books and the church plate, portraits of church donors, the documents found embedded in the walls, the Bulgarian church archives, etc. All this will forever testify for the love and brotherhood of the Romanian people and the Romanian Church towards the Bulgarian Church and the Bulgarian people .... ${ }^{628}$ In response to this message addressed to him and the Bulgarian Church, Patriarch Cyril said: "With great gratitude are filled our hearts from these brotherly greetings of the Most Blessed Justinian, Patriarch of the Holy Romanian Orthodox Church, to which we have long been obliged with sincere love for the love that feeds on our Holy Church ... "29

On October 11, 1954, Patriarch Cyril made his first visit to Romania, as a Bulgarian Patriarch. He was solemnly welcomed on the Romanian coast of the Danube River by father Radu Pavel from Giurgiu. ${ }^{30}$ In response to this kindly welcome, Patriarch Cyril said: "To be blessed our step in Romanian land; to be blessed and your wonderful homeland ". ${ }^{31}$

In Bucharest, in Patriarchal House, Patriarch Cyril was greeted by Patriarch Justinian and a large number of clerics. On the same day Patriarch Cyril was also accepted by the Minister of Cults of Romania - Academician Constantinescu - Iasi. ${ }^{32}$ On October 12, 1954, patriarch Cyril and the Bulgarian delegation worshiped in the Patriarchal Cathedral of St. St. Constantine and Helena at the relics of St. Dimitar Bessarbovski, who forever connected in Christ love the Bulgarian and Romanian people, after that they went on pilgrimage trip to the Tsiganesti, Plumbuita and Antim monasteries. In the monastery of Tsiganesti, Patriarch Cyril was pleasantly surprised by the fact that among the sisters of the monastery, which were 200 in number, there were also nuns with Bulgarian origin. ${ }^{33}$ At the solemn lunch given by Patriarch Justinian, the two again discussed the financial status of churches and monasteries, the administration of the monasteries and the introduction of labor in the monasteries, despite the resistance of some monks who thought they would be diverted from their prayer duties. ${ }^{34}$ Patriarch Cyril remained pleasantly surprised by the fact that the Romanian Patriarchate had a department that controls the iconography throughout the country in order to avoid deviations from the canon, as well as a Department of

\footnotetext{
${ }^{28}$ Ibidem, pp. 186-187.

${ }^{29}$ Ibidem, p. 204.

${ }^{30}$ Кирил Патриарх Български. Дневници..., p. 186

${ }^{31}$ Ibidem.

${ }^{32}$ Ibidem, p. 187.

${ }^{33}$ Ibidem, pp. 187-189.

${ }^{34}$ Ibidem.
} 
Architecture, where several architects worked. ${ }^{35}$ The Bulgarian patriarch was heavily impressed by the many workshops at the Antim monastery, where were made from packing boxes, to priestly garments, plates and bells. In the memorial book of the monastery he recorded: "We visited all the ateliers of the Patriarchy and are delighted with what we saw, that testifies to the great organizational and creative gifts of His Holiness the Romanian Patriarch Justinian. We pray for the Romanian Church, for new spiritual and material creative achievements" ${ }^{36}$ Patriarch Cyril was also fascinated by the organization and number of religious books, magazines, newspapers and textbooks published by the "Printing and Publishing Department", headed by father Gregory Vurluşanu. In the memorial book he noted: "Our impressions of the structure and activity of the Patriarchal Printing house and the other wards are wonderful. May God bless this work". ${ }^{37}$

On October 13, 1954, Patriarch Cyril visited the city of Iasi, where he was welcomed at the station by a vast array of believers and clerics. In the Metropolitan house, Metropolitan Sebastian met Bulgarian delegation with a solemn greeting to the Bulgarian patriarch. The choir of priests was singing on Slavonic perennial (Many years) ${ }^{38}$ In Iasi Patriarch Cyril visited the churches " The Three Holy Hierarchs "," St. Nicholas Royal "," St. Paraskeva "and the monasteries of Golia, Galata and Cetățuia, where Patriarch Justinian became a monk. In the church of "St. Paraskeva", the two Patriarchs served a solemn service in front of the saint's relics. ${ }^{39}$ On the following day, Patriarch Cyril visited again the church of St. Paraskeva to worship the saint's holy relics and after that continued to the Neamt Monastery. ${ }^{40}$ Patriarch Cyril was warmly greeted in the monastery by the monastery brotherhood, who were singing church songs for the Bulgarian patriarch. Eight deacons with censers in hand were built in two rows.

Patriarch Cyril was very impressed and with excitement pronounced a short speech in which said, that he finally visited this remarkable monastery, something, he wanted from his youth to do. ${ }^{41}$ During the solemn lunch, he was pleasantly surprised to see his professor from the Theological Faculty of Chernivtsi - Father Professor Vasily Georgiou. Iasi Metropolitan Sebastian was guilty for the surprise, he sent his private car to the village of Kut (some $50 \mathrm{~km}$. from Neamt monastery), to make possible for Patriarch Cyril to see his 83 years old friend and professor. Prof. Georgiou also met with another friend, the famous Bulgarian scholar Priest Professor Stefan Tsankov. They have been close friends for many years and knew each other from numerous theological meetings and conferences in Europe. Father Prof. Vasily Georgiou taught Greek and New Testament in Chernivtsi and was a scientific tutor of Patriarch Cyril during his doctoral studies there. Later on Patriarch Cyril with interest looked at the library of the Neamt Monastery, which preserved many Slavonic manuscripts and represented tremendous wealth and interest for future research, but he also regretted that the library was not cataloged. During the dinner was raised by Metropolitan Sebastian and discussed a very important issue, which to this day has not found its solution the Second marriage of the Priesthood. ${ }^{42}$

${ }^{35}$ Ibidem, pp. 191-192.

${ }^{36}$ Ibidem, p. 191.

${ }^{37}$ Ibidem, p. 192.

${ }^{38}$ Ibidem, p. 193.

${ }^{39}$ Ibidem, p. 195.

${ }^{40}$ Ibidem.

${ }^{41}$ Ibidem, p. 197.

${ }^{42}$ Ibidem, p. 198. 
Patriarch Cyril also visited the monk seminary and the school for Church singers in the monastery. On the following day, Patriarch Cyril on his way to the monastery of Agapia went to the village of Humulesti, to visit and bow to the museum and home of the great Romanian writer Ion Creanga. ${ }^{43}$ At the monastery of Agapia Patriarch Cyril was greeted by the monastery sisterhood headed by the abbess of the monastery. The Patriarch was again fascinated, the monastery had 550 nuns and novices. The church of the monastery "St. Archangel Michael "was wonderful. Church was painted in the middle of the 19th century by the notable Romanian painter Nicolae Grigorescu. Grigorescu painted the temple when he was only 19 years old. The frescoes, as noted by Patriarch Cyril, were wonderful, but not in Byzantine style. ${ }^{44}$ Subsequently, Patriarch Cyril in his "Diaries" detailed the entire history of the monastery, from its foundation in the 16th century by the monks Agapius and Efrosin, to the present day. ${ }^{45}$ Patriarch Cyril does not fail to note yet another very impressive fact, that in Oltenia all monasteries are dormitory and that there were more than 2,000 monks and nuns in the Moldavian diocese. ${ }^{46}$ The next day, October 17, 1954, Patriarch Cyril headed a solemn Holy Liturgy in the Neamt Monastery, to which many nuns from the Agapit and Varatec monasteries came. ${ }^{47}$ During the service, Patriarch Cyril tonsured the monk Victorine as a reader and subdeacon, and then ordained him a deacon. ${ }^{48}$

From the Neamt Monastery, Patriarch Cyril briefly stopped in city Roman, where he was again greeted by thousands of people. There, in the local temple, he did a brief prayer and spoke briefly to the local citizens. The bishop of the city Roman - Theophilus and Metropolitan Sebastian also spoke shortly. From Roman Patriarch Cyril returned to Bucharest, where, after a short break, on 19 October 1954, he departed for Curtea de Arges. ${ }^{49}$ In the monastery he was welcomed by his classmate from Chernivtsi, Bishop Paul. Patriarch Cyril did not save words of praise to describe the monastery church of the "Dormition of the Theotokos", the monastery itself and its large park, as well as the monastery's old literature richness. ${ }^{50}$

Patriarch Cyril does not miss to mention the earliest frescoes in the old church from the 14th century, which were in Slavonic language. ${ }^{51}$ On October 20, Patriarch Cyril went to Craiova, and here he did not save his praise, both for the city itself and for the meeting organized by Firmillian, the Archbishop of Craiova and the Metropolitan of Oltenia. In Craiova Patriarch Cyril worshiped in the cathedral "St. Dimitar "at the relics of St. Neophyte patriarch of Constantinople, St. Sergius and Baccus and martyr Tatiana. In the cathedral he also pronounced a brief, but heartily speech: "... here we also, coming here in your blessed temple, saw your piety and your love for the Church, to God, to us, who came from foreign country and represent a Sister Church ... Be blessed! ${ }^{652}$ Patriarch Cyril visited also the church of "St. Virgin Mary“ - Mântuleasa ,where also spoke in a short welcoming speech. The visit is followed by a solemn lunch in the Metropolitan home with Archbishop Firmillian, the lunch went into a fraternal, intimate atmosphere. On the following day

\footnotetext{
43 Ibidem, p. 199.

${ }^{44}$ Ibidem, p. 200.

${ }^{45}$ Ibidem, pp. 200-201.

${ }^{46}$ Ibidem, p. 201.

${ }^{47}$ Ibidem, p. 201.

${ }^{48}$ Ibidem, p. 202.

${ }^{49}$ Ibidem, p. 203.

${ }^{50}$ Ibidem, pp. 204-205.

${ }^{51}$ Ibidem, p. 205.

${ }^{52}$ Ibidem, p. 206.
} 
Patriarch Cyril visited four churches in Raminicu Valcea and then went to visit the Horezu Monastery, where again was greeted with great love. ${ }^{53}$ Patriarch Cyril describeed in details the history and architecture of the monastery, as well as the holy relics that were preserved in it. $^{54}$

The next day Patriarch Cyril visited Bistritca Monastery, and on 23 October is again in Bucharest. ${ }^{55}$ In Bucharest Patriarch Cyril spent a tiring, but extremely pleasant week, in which he was a dear guest of Patriarch Justinian, visiting a number of churches, meeting with many bishops, theologians, artists, etc. As he himself puted it: "We could see almost all the Diocesan archbishops. That was how Patriarch Justinian had ordered". 56

In Bucharest, besides the regular worship services, he also had a number of conversations and was particularly impressed by the discipline in the Romanian Church, something that explicitly emphasized. ${ }^{57}$ During this visit to Romania, as a sign of profound respect for Patriarch Cyril's personality and brotherly love for the Bulgarian people and the Church, Patriarch Justinian donated for use by the Bulgarian community in the city until the construction of his own temple, the church "St. Iliya ". ${ }^{58}$ On October 29, 1954, Patriarch Cyril flew back to Bulgaria in the early afternoon. At the airport was sent by Patriarch Justinian and a number of other Romanian clerics, as well as by the director of Romania's Ministry of Cults, Ion Dumuchuscu, and by the Bulgarian Ambassador Stoyan Pavlov.

\section{CONCLUSION}

In the following 1955, a delegation of the Bulgarian Orthodox Church headed by Patriarch Cyril also visited Romania, but in his "Diaries" there are no pages for this visit. ${ }^{59}$ Patriarch Cyril repeatedly through the years visited the city of Bucharest for a short time on his way to Moscow and repeatedly meets with Patriarch Justinian at various Orthodox forums and conferences around the world. ${ }^{60}$

The last visit of Patriarch Cyril to Romania was in June 1968 at the celebrations marking the 20th anniversary of Patriarch Justinian's enthronement. For the strong spiritual tie that connected Patriarch Justinian and Patriarch Cyril speaks of the fact that not all the Heads of local Orthodox Churches were invited to the celebrations of this round anniversary. Amongst the uninitiated was and Serbian Patriarch German, who looked for advice and assistance from Patriarch Cyril how to deal with the case. Patriarch Cyril advised him to send Patriarch Justinian a congratulatory telegram. ${ }^{61}$

After the celebrations, Patriarch Cyril remained in Bucharest for a while, and with the assistance of Patriarch Justinian received permission to work in the Diplomatic Archive at the Romanian Ministry of Foreign Affairs. Patriarch Cyril was received with great attention by Minister Dionysius Ionescu, who fully cooperated his scientific research. ${ }^{62}$ In

\footnotetext{
53 Ibidem, p. 209.

${ }^{54}$ Ibidem.

${ }^{55}$ Ibidem, p. 211.

${ }^{56}$ Ibidem, p. 215.

${ }^{57}$ Ibidem.

${ }^{58} \mathrm{https} / / /$ dveri.bg/a6uda посетен на 3.04.2018

${ }^{59}$ Кирил Патриарх Български. Днивници..., p. 586.

${ }^{60}$ Ibidem, pp. 307, 627.

${ }^{61}$ Ibidem, pp. 581-582.

${ }^{62}$ Ibidem, p. 589.
} 
his "Diaries", Patriarch Cyril laconically, but eloquently wrote: "In the Archive, people were extremely careful to me, even more than I could expect." ${ }^{163}$

On March 7, 1971, after a severe illness, the great friend of the Romanian people and Church died, Patriarch Cyril of Bulgarian. On March 26, 1977, the great friend of the Bulgarian people and Church presented himself to the Lord, Romanian patriarch Justinian (Marina). God to forgive and reassure their souls and may their holy prayers to continue to strengthen the bonds between the two sisters Churches, the Bulgarian and the Romanian.

\section{BIBLIOGRAPHY:}

[1] Righteous Among the Nations Honored by Yad Vashem by 1 January 2017 http://www.yadvashem.org/yv/pdf-drupal/bulgaria.pdf visited 06.04.2018.

[2] Димов, Я. Кирил „Патриарх Български“. София, 2005, pp. 67, 73 и сл. Димов, Я. Не си прави кумир. Ч. I, София, 1992,

[3] Павлов, П. Патриарх Кирил: опит за жизнеописание. - В: Сборник в чест на Кирил патриарх Български. Пловдив, 2001, p. 13. Ковачев, М. Негово Светейшество Българският патриарх Кирил и преглед на книжовното му дело. - ГДА, т. ХІІІ, 1964,

[4] Омарчевски, А. Участието на Негово Светейшество Патриарх Кирил във възстановяването на Българската Патриаршия. - В: Сборник в чест на Кирил Патриарх Български (по случай 100 години от рождението и 30 години от неговата смърт). Пловдив, 2001,

[5] Деяния совещания глав и представителей автокефальных Православных церквей в связи с празднованием 500 летия автокефалии Русской Православной церкви 8 - 18 июля 1948 г. Т. 1. Москва, 1949.

[6] Кирил Патриарх Български. Дневници (съст. И ред. Ж. Лефтеров, М. Методиев). София, 2018

[7] Stanciu, C. A Rebirth of Diplomacy: The Foreign Policy of Communist Romania between Subordination and Autonomy, 1948-1962. - Diplomacy \& Statecraft, vol.24, issue2, 2013,

[8] Патриарх Кирил. Българомохамедански селища в Южни Родопи: Топонимно, етнографско и историческо изследване. София, 1960.

${ }^{63}$ Ibidem, p. 590. 